\title{
IN MEMORIAM S. DU TOIT
}

Hoe afgetrokke en eiesoortig die akademiese aktiwiteit aan 'n universiteit ook al mag lyk, vir die effektiewe verloop daarvan is 'n gesonde administrasie-struktuur absoluut noodsaaklik. Hoewel laasgenoemde nie 'n waarborg vir die hoë peil aan 'n universiteit kan wees nie, is dit 'n noodsaaklike voorvereiste. Hierdie doeltreffende administrasie is ten nouste verbonde aan die persoonlikheid van die registrateur.

So het die P.U. vir C.H.O. die voorreg gehad om 'n registrateur met buitengewone gawes tot sy beskikking te hê. Wyle mnr. S. du Toit het saam met die Universiteit gegroei en 'n belangrike aandeel aan die ontwikkeling daarvan gehad. Dit is vandag moeilik om hierdie aandeel presies te bepaal, maar oor die algemeen kan, sonder vergroting, gekonstateer word dat mnr. Du Toit in haas elke groot onderneming van die Universiteit betrokke was. Die welsyn en vooruitgang van sy inrigting het hom vreugde verskaf, maar menige dag seker ook spanning en bekommernis.

Indirek het mnr. Du Toit aan „Koers” ook sy aandeel gehad. Die stryd om die voortbestaan van ons blad het nie onopgemerk by hom verby gegaan nie. Sy raadgewing het getuig van rype insig en belangstelling.

Die Redaksie en Direksie van „Koers” wil graag hiermee dankbare hulde bring aan die nagedagtenis van mnr. Du Toit. Aan die agtergeblewe eggenote, kinders en familiebetrekkinge betuig ons ons hartlike meelewing in hulle smartlike verlies.

W. N. Coetzee. 
